\title{
Microbial Forensics: Bioterrorism and Biocrime
}

\author{
Yong-Bin Eom ${ }^{\dagger}$ \\ Department of Biomedical Laboratory Science, College of Medical Sciences, \\ Soonchunhyang University, Asan, Chungnam 31538, Korea
}

\begin{abstract}
Microbes and their toxins can be bioweapons that bioterrorists use them to commit bioterrorism and biocrime. Due to the potential and relative ease of the bioattack, life-threat pathogenic agents (bacteria, viruses, and toxins) as bioweapon revealed the need for a new field of microbial forensics. Microbial forensics is a new scientific discipline combining microbiology and forensic science, which is focused on characterization of evidence from a bioterrorism, biocrime, and an inadvertent release of biothreat agents. The sophisticated analytical tool and knowledge of microbial forensics can provide investigative leads and help determine who was responsible for the biocrime, the source of the bioweapon, and how and where the bioweapon was produced. Among the fields of microbial forensics, this paper will briefly describe evidence collection, handling, packaging, transportation, storage, analytical methods of evidence, and review microbial forensics as a response to bioterrorism and biocrime.
\end{abstract}

Key Words: Microbes, Microbial forensics, Bioweapon, Bioterrorism, Biocrime

\section{서 론}

미생물은 수세기 동안 생물무기(bioweapon)로서 사용가 능성이 제기되어 왔지만(Lederberg, 2000), 2001년에 미국 에서 발생한 911 테러 이후 탄저균 아포 편지봉투 공격으 로 인해 대중에게 널리 알려지기 시작하였다(Read et al., 2002). 이러한 생물테러(bioterrorism)에 대한 대응은 미국 뿐만 아니라 전세계적으로 취약한 상태였고, 생물무기로 사용된 원인체를 확인하고 병인론을 결정하는데도 많은 어려움을 있었기 때문에 결과적으로 미국을 비롯한 여러 국가에서 법미생물학(microbial forensics) 분야의 발전은 필 수적이었다. 법미생물학자는 기존의 과학적 범죄수사 분 야인 범죄현장 조사, 증거물 관리의 연속성(chain of custody), 증거물 채집, 처리 및 보관, 증거물 운송, 분석, 결과 의 해석을 법정에서 증언하는 등의 분야 외에 생물무기로
사용된 증거물의 기원을 정확하게 확인하기 위해 병원체 를 분리하여 그 원인체에 대한 충분한 정보를 제공해야 할 임무가 추가되었다.

법미생물학 분야는 다학제간(예를 들면, 미생물학, 유전 체학, 생물정보학, 법과학, 면역학, 인구유전학, 생화학, 분 자생물학, 역학 등)의 전문 분야와 경찰행정학, 공중보건 학, 정책 및 지능 범죄수사학 등의 다양한 전문가 네트워 크의 연계가 필요하다. 특히 법미생물학은 병원체나 독소 를 개별 분리하여 어떻게 생산되어 배포되었는지 등을 집 중적으로 조사해서 생물테러리스트(bioterrorist)와 생물범 죄자(biocrime perpetrator)를 확인하는데 목적을 두고 있다 (Schmedes et al., 2016).

인간의 생명과 건강을 위협하는 미생물 균주는 약 1,400 여종 이상이며, 식물과 동물 병원체까지 고려하면 그 수는 엄청나게 늘어난다(Taylor et al., 2001). 이렇게 수많은 병원 체를 정확하게 분석하기 위해서는 유전체를 높은 처리량

* Received: March 5, 2018 / Revised: March 16, 2018 / Accepted: May 29, 2018

†Corresponding author: Yong-Bin Eom. Department of Biomedical Laboratory Science, College of Medical Sciences, Soonchunhyang University, 22 Soonchunhyang-ro, Shinchang-myeon, Asan-si, Chungcheongnam-do 31538, Korea.

Tel: +82-41-530-3039, Fax: +82-41-530-3085, e-mail: omnibin@sch.ac.kr

(C) The Korean Society for Biomedical Laboratory Sciences. All rights reserved.

(C) This is an Open Access article distributed under the terms of the Creative Commons Attribution Non-Commercial License (http://creativecommons.org/licenses/by-nc/3.0/) which permits unrestricted non-commercial use, distribution, and reproduction in any medium, provided the original work is properly cited. 
으로 신속하게 분석 가능한 대용량 병렬 염기서열 분석 법(massively parallel sequencing; MPS) 또는 고효율 처리량 염기서열 분석법(high-throughput sequencing; HTS) 기법이 필수적이다. 이러한 분석법들로 인해 기존에 알려지지 않 았던 병원체의 동정, 혼합 증거물에서 미세한 양으로 존재 하는 미생물들을 확인하는 것이 가능하게 되었다. 2001년 탄저균 아포 생물테러의 증거물에서 Bacillus anthracis 균 주의 염기서열을 확인함으로써 그 것이 B. anthracis Ames strains 임을 밝혀졌다(Rasko et al., 2011; 2013).

본 논문에서는 법미생물학의 개념, 증거물의 채집, 포장, 운송, 보관 방법 및 전략에 대해 모색하고 생물테러에서 주로 사용되는 미생물의 종류와 그 기원을 추적하는 여러 가지 분석 기법들에 관해 살펴보고자 한다.

\section{본 론}

\section{증거물 채집(Evidence collection)}

일반적으로 기본적인 범죄현장 조사 기법이 생물테러 및 생물범죄 사건에도 적용된다(FBI, 2013). 제일 먼저 최우선 적으로 취해야 할 것은 피해자를 보호하는 것이고, 공중 보건 위험을 차단하는 것이다(Schutzer et al., 2005). 그 후 에 범죄현장을 보존하고, 범죄현장 조사자는 사건 자료를 수집한 일차대응기구나 조사팀의 사전 정보를 따른다. 사 전계획 수립은 필수적인 작업으로 적절한 시간 내에 미생 물범죄 증거물을 채집, 처리해야 하는 작업에 대해 치밀 하게 계획해야 한다(Budowle et al., 2006).

생물테러나 생물범죄 현장에서 증거물 채집은 희생자와 주변 환경으로부터 둘다 검체를 채취해야 생물위협 원인 체를 동정하고 그 기원을 추적하며 추후 재판과정에서 증 거로 채택을 준비할 수 있다. 증거물은 세 가지의 일반적 접근에 의해 채집이 가능하다. 첫 번째 접근 방법은 시료 전체를 수거하여 밀폐된 멸균 용기로 운반하는 것이다. 이 방법은 조사자가 보호장구를 착용하는 것이 중요하고 증 거물 채집에 필요한 시간을 최소로 한다. 일단 증거물이 안전한 장소로 운반되면 좀더 엄격한 평가와 자세한 채집 이 적절한 밀폐 조건하에서 수행될 수 있다. 두 번째로 전 체 증거물의 수집이 어렵다면 범죄현장 조사자는 증거물 의 일부만을 채집하는 방법이 있다. 세 번째로 미세한 증 거물의 경우에는 적절한 도구를 사용해서 쓸거나 닦아서 채집하는 방법이 있다. 맞춤형 채집 전략은 생물무기가 의 심되거나 잠재적인 병원균에 대한 정보가 있을 때 고려되 어야 한다(Budowle et al., 2005b; Budowle et al., 2006).
일반적인 범죄수사 과정에 적용하는 표준작업절차(SOP) 의 엄격성이 생물테러 사건이나 생물범죄에서는 비현실적 일 수 있다. 범죄현장이 일정한 형태나 틀에 맞는다면 증 거물 채집 작업이 쉽게 설명될 것이지만, 대부분의 미생 물범죄 사건에서는 채집 범위, 지역, 병원체, 기질, 복합체 등은 언제나 변화될 수 있다. 모든 범죄현장은 각기 다르 고 각각의 변수가 매우 크기 때문에 증거물 채집과정에 서 어느 정도의 융통성은 필요하다. 더군다나 미생물이나 $\mathrm{DNA}$ 에 대한 채집 조건은 주변 환경으로부터 오염을 피 하는 증거물 채집 방법이 중요하고, 독소의 경우 독소가 포함되어 있을 가능성이 있는 주변 증거물 모두를 채집하 는 것이 요구된다(Budowle et al., 2006).

증거물 채집 방법이나 도구에 관해서는 다음의 세 가지 고려사항이 있다. 첫 번째는 증거물 채집 방법과 도구 중 일부는 완벽하게 검증되지 않았다는 점이다. 두 번째는 이 미 검증 받은 증거물 채집 방법의 경우, 보안상의 이유로 검사 기관간의 공유가 원활하지 못하여 실제로 이것이 필 요한 경우 방법을 습득할 기회가 매우 적다는 점이다. 세 번째는 조사자기 사전에 분석대상과 분석 결과에 대해 충 분히 이해한 다음 이에 맞추어 적절한 방법이 사용되어야 한다는 점이다. 사실 각각의 사건의 불확실성, 여러 미생 물들의 다양성, 분석물의 안정성 등으로 법미생물학 종사 자들에게 이러한 것들을 모두 고려하는 것은 쉬운 것이 아니다. 어떤 산소성 미생물에게 공기중 산소의 노출이 허 용되는 증거물 채집 방법이 무산소성 미생물에게는 적절 하지 않을 수도 있다(Schutzer et al., 2005). 따라서 여러 가 지 다른 방법을 동시에 시행하는 것이 좋다(Budowle et al., 2006).

최적의 증거물 채집 전략은 범죄현장 조사에 대해 기존 에 수립된 가이드라인을 준수하고 이와 더불어 전문가 의 견, 미생물학 및 생화학적 지식, 조사자의 경험 그리고 일 반 상식 등을 추가하여 종합적으로 판단하는 것이다. 어 떤 특별한 경우에는 기존의 증거물 채집법이나 도구 없이 새로운 방법이나 직관적 방법이 실행될 수 있다. 만약 이 때 새로운 방법을 시행한다면 모든 과정들은 추후 참고 자료나 조사를 위해 반드시 기록해야 한다(Budowle et al., 2005b; Budowle et al., 2006).

증거물 채집 방법과 도구는 전 분석과정과 더불어 검 증을 받아야 한다. 이때 검증은 채집에서 분석까지의 전 과정을 포함해야 한다. 채집 시에 사용되는 어떤 면봉의 경우, 용해 물질(지방산)을 가지고 있어 세포배양에 독성 을 갖거나 박테리아의 배양을 저해할 수도 있어 Calcium 
alginate나 Dacron 섬유로 만든 것이 추천된다. 특정 병원 균을 보존할 때에 사용되는 어떤 물질(glycerol 또는 skim milk)은 추후 분석과정에 저해를 할 수도 있다(Baron and Thomson, 2011; Baron, 2015). 박테리아를 함유하는 증거 물은 일반적으로 운송배지로 운반된다. 바이러스의 경우 에도 PBS (phosphate buffered saline) 배지나 BSA (bovine serum albumin)와 항생제를 첨가한 HBSS (Hanks balanced salt solution) 배지를 주로 사용한다. 어떤 동물 바이러스의 안전성은 특별히 $\mathrm{pH}$ 와 이온 강도에 의해 영향을 받기 때 문에 일반적으로 흔히 사용되는 배지는 buffered tryptose broth이다. 국제적으로 vesicular disease에 널리 사용되는 buffered glycerin는 실온에서 병원성 바이러스를 장시간 보 존하는 것으로 밝혀졌다. 그러나 glycerol의 경우 특정 농 도에서 임상시료에서 보존하는 동안 특정 바이러스를 저 해할 수도 있다(van Baare, 1994; Marshall L, 1995; van Baare et al., 1998).

\section{증거물의 포장, 운송, 보관(Packaging, transport, and preservation)}

증거물의 분석 결과는 시료가 포장, 운송, 보관되는 조 건에 의해서 영향을 받는다. 보관 조건은 미생물에 따라 다른데, 무산소성 미생물의 경우는 보관 도중 공기의 산소 농도를 접하게 되면 추후 배양이 안될 수도 있다(Baron, 2015). 포장 또는 보관 조건은 시료의 기질이나 물리적 조 건에 따라서도 역시 다르다. 매우 소량의 증거물만 있다 면 단 한번의 채집만 가능할 것이고 이런 환경에서는 증 거물을 온전하게 유지하는 것이 매우 중요하다.

대부분의 박테리아를 위한 포장운송법은 바이러스 병원 체에는 부적당하다(Hosokawa-Muto et al., 2015). 운반 방법 은 훼손, 결손, 오염을 최소화하고 인체에의 노출을 차단 해야 한다(Wegerhoff, 2006). 어떤 시료는 실온에서 운반될 수 있지만, 어떤 것은 냉장상태로 운반되어야 한다(Wilson, 1996). 대부분의 임상 검체는 냉장 조건에서 보관한다. 운 반과 보관과정 중에 팽창되는 것을 막기 위해 시료를 동 결, 건조하기도 하는데, 어떤 미생물들은 동결에 의해 영 향을 받을 수 있기 때문에 buffered glycerol을 사용해서 동 결, 해동으로 인한 피해를 최소화 한다(Kotula et al., 1979). 그러나 생물테러나 생물범죄 사건현장에서 최적의 운반 물질이나 과정을 예측하는 것은 어렵기 때문에, 범죄현장 조사자들은 다양한 보관 조건을 준비하고, 포장 및 운송 전에 전문가의 조언을 구해야 한다.

생물테러 사건이 농업을 상대로 발생한다면, 작물과 환
경 시료가 필요할 것이다(Kuiper, 2016). 즉, 식물 조직 시 료와 곤충, 선충, 토양 또는 물과 같은 환경 시료를 직접 멸균 용기 내로 채집한다. 곰팡이 균사나 포자, 박테리아 등의 균체는 식물체 표면이나 토양으로부터 추출하여 멸 균수 또는 PBS, $70 \%$ 에탄올 등이 들어있는 용기에 보관 한다(Belser and Mays, 1980).

범죄현장 부근의 환경에서도 많은 시료들이 채집되는 경우가 있다. 이러한 경우에 증거물의 상태에 대해서도 고려해야 한다(McBride and Gilpin, 2016). 가령, 건조 물질 을 냉각시키는 것은 수축작용으로 물리적 상태를 변형시 켜 이후의 분석과정을 방해할 수 있다. 일반적으로 채집 된 환경 시료는 멸균 상태로 레이블링 되어 있는 지퍼식 비닐 봉투에 넣어 실온에 보관한다. 생물범죄 증거물의 경 우에는 시료를 원상태 유지가 매우 중요하다(Budowle et al., 2006).

\section{범죄수사의 시료 채집 전략(Forensic sampling strategy)}

범죄수사에서 무작위 시료 채집법은 적절치 않다. 가령 병원균을 동정하기 위해서 전체 집단 중 피해 증상을 보 이는 개체에서만 채집하는 것이 효과적이다. 또한 범죄수 사에서 사건의 사전 정보를 파악하고 가능한 한 높은 가 능성을 보이는 방법에 우선 순위를 주어야 한다(Budowle et al., 2008). 통계적 채집이나 무작위 시료 채집이 범죄수 사에서는 흔히 쓰이는 방법은 아니지만, 몇몇의 사건에서 는 필요할 수도 있다. 예를 들어 다른 환경 요인을 비교할 때 시료 간 변이 정도를 파악하기 위해서 통계적 방법이 요구된다(McBride and Gilpin, 2016). 여러 지역이나 많은 시료량이 채집되었을 때도 지역 특이성을 결정짓는 대조 군 시료를 채집할 필요가 있다. 이런 점에서 미생물 병원 체의 생물지리학적(biogeographic) 고려가 중요하다. 생물 지리학에 관한 경험적 관찰은 지역 특이성이나 특정 병원 체의 유입에 관한 중요한 단서를 제공한다(Martiny et al., 2006). 증거물 채집 전량은 범죄 상황에 대해서 사전 정보, 채집된 병원체의 특성, 재생 효과, 채집예상 미생물의 배 양 가능 여부, 생물체의 생리학적 단계, 기타 다른 특성 등도 고려해야 한다(Javan et al., 2016). 미생물범죄 조사의 성공 여부는 현장수사의 초기 단계에 달려 있는데, 이것 은 채집, 처리, 보존에 의존한다. 따라서, 생물무기가 관련 된 범죄의 수사를 위한 미생물 증거물의 채집계획, 검증, 신뢰성 등을 높이기 위한 다양한 노력들이 시행되어야 할 것이다(Budowle et al., 2006). 
Table 1. CDC Emergency preparedness and response for bioterrorism

\begin{tabular}{|c|c|c|}
\hline Category & Agents & Diseases \\
\hline \multirow{7}{*}{ A } & Bacillus anthracis & Anthrax \\
\hline & Clostridium botulinum toxin & Botulism \\
\hline & Yersinia pestis & Plague \\
\hline & Variola major & Smallpox \\
\hline & Francisella tularensis & Tularemia \\
\hline & Filoviruses (Ebola, Marburg) & Viral hemorrhagic fever \\
\hline & Arenaviruses (Lassa, Machupo) & \\
\hline \multirow{14}{*}{ B } & Brucella spp. & Brucellosis \\
\hline & Epsilon toxin of Clostridium perfringens & \\
\hline & Salmonella spp. & Food safety threats \\
\hline & Shigella spp. & \\
\hline & Escherichia coli $\mathrm{O} 157: \mathrm{H} 7$ & \\
\hline & Burkholderia mallei & Glanders \\
\hline & Burkholderia pseudomallei & Melioidosis \\
\hline & Chlamvdia psittaci & Psittacosis \\
\hline & Coxiella burnetii & Q fever \\
\hline & Ricin toxin from Ricinus communis (castor bean) & \\
\hline & Staphylococcal enterotoxin B & \\
\hline & Rickettsia prowazekii & Typhus fever \\
\hline & $\begin{array}{l}\text { Alphaviruses (such as Eastern equine encephalitis, Venezuelan } \\
\text { equine encephalitis, Western equine encephalitis) }\end{array}$ & Viral encephalitis \\
\hline & Vibrio cholerae, Cryptosporidium parvum & Water safety threats \\
\hline $\mathrm{C}$ & Nipah virus and Hantavirus & Emerging infectious diseases \\
\hline
\end{tabular}

\section{생물테러와 생물범죄에서 사용될 가능성 있는 미생물} (Potential pathogens for bioterrorism and biocrime)

미국 질병통제예방센터(CDC)에서 공중보건에 미치는 영향, 미생물 전파 및 전염의 용이성, 공중보건 대비에 대 한 요구사항, 사회적 혼란에 미치는 정도에 따라 3 가지 카테고리로 분류한 생물테러에서 사용될 가능성이 있는 미생물의 종류는 Table 1과 같다(CDC, 2017).

카테고리 $\mathrm{A}$ 는 사람들 사이에 쉽게 전파 및 전염이 되고 높은 치사율을 야기하며 공중보건에 심각한 영향을 미쳐 대중을 공황 상태에 빠트리고 사회적 붕괴를 야기시킬 가 능성이 있어 공중보건 대비를 위해 특별한 활동을 요구하 는 가장 위험성이 높은 병원체들이다. 카테고리 $\mathrm{B}$ 는 전파 가 중등도로 쉽고, 중간 정도의 유병율과 낮은 치사율을 보이며 질병의 감시와 진단 능력을 향상시킬 필요성이 있 는 두 번째로 위험성이 높은 경우이다. 카테고리 $\mathrm{C}$ 는 향 후 대량 전파를 위해 유전자 조작될 가능성이 있는 새롭 게 출현하는 병원체를 포함하는 세 번째로 위험성이 높은 경우로, 생산과 전파가 용이하고, 높은 유병율과 치사율의 잠재력을 가지고 있어 공중보건에 주요한 영향을 미칠 목 적으로 사용가능성이 있는 경우이다(CDC, 2017). 또한 실 제 생물테러와 생물범죄에서 생물학적 무기가 사용된 사
례는 Table 2와 같다.

매트릭스-보조 레이저 탈착 이온화-비행 시간 질량분석 기(Matrix-assisted laser desorption ionization-time of flight mass spectrometry; MALDI-TOF MS)

기존의 미생물 균종 동정은 전통적 표현형 시험(주로 배양에 의한 생화학적 시험)이 오랫동안 이용되어 왔지만, 검사시간이 길고 일부 균종의 동정은 정확하지 못하였다. MALDI-TOF MS법으로는 빠르고 정확한 균종 동정이 가 능하고 술식이 간단하며 필요한 장비의 가격이 점차 내려 가므로 여러 미생물 검사실에서도 이용되고 있다(Jung et al., 2017).

MALDI-TOF MS법에 의한 균종 동정 원리를 살펴 보면, 세균이나 진균 집락을 matrix라고 부르는 낮은 질량(mass) 인 유기화합물과 섞어서 금속판(metal target plate)에 한 방 울 놓는다(Ho et al., 2009). 건조되면 검체와 matrix가 함께 결정을 이루며 matrix는 검체의 이온화에 필요하다. 금속 판 위에 놓인 검체-matrix의 결정체에 $\mathrm{UV}$ 레이저 광선(파 장 $337 \mathrm{~nm}$ 인 N2 레이저가 대개 쓰임)을 파동성으로 쪼이 면 레이저 광의 에너지를 흡수하여 레이저의 광자(photon) 들과 matrix 분자들이 상호작용을 일으키고 matrix가 기체 상태로 승화(sublimation)되고 이어서 검체 중의 단백질이 
Table 2. Examples of microbial forensic cases using bioweapons in bioterrorism and biocrime

\begin{tabular}{|c|c|c|c|c|}
\hline Year & Location & Pathogen/toxin & Introduction route & Diseases \\
\hline 1990 & Australia & HIV-tainted blood & Injection & AIDS \\
\hline 1992 & Missouri & HIV-tainted blood & Injection & AIDS \\
\hline 1994 & Louisiana & HIV-tainted blood & Injection & AIDS \\
\hline 1994 & Holland & HIV-tainted blood & Injection & AIDS \\
\hline 1995 & Missouri & Ricin & Food contamination & Poisoning symptoms \\
\hline 1996 & Texas & Shigella dysenteriae type 2 & Food contamination & Shigellosis \\
\hline 1997 & New Zealand & Rabbit hemorrhagic fever virus & Injection, food contamination & Hemorrhagic disease \\
\hline $1990 \mathrm{~s}$ & Japan & Bacillus anthracis, botulinum toxin & Aerosol & Anthrax, spasticity \\
\hline 2001 & USA & Bacillus anthracis & Letters & Antrax \\
\hline
\end{tabular}

이온화 된다. 이온화된 단백질은 time of flight (TOF) 관을 통과하여 검출기에 도달한다. 이온화된 단백질이 $\mathrm{TOF}$ 관 을 통과하는데 걸리는 시간은 질량이 작으면 짧고 크면 길다(Fenselau and Demirev, 2001; Petersen et al., 2009). 검출기 는 질량 $(\mathrm{mass})$ 과 하전(charge)의 비율 $(\mathrm{m} / \mathrm{z})$ 즉 이온화된 단 백질이 $\mathrm{TOF}$ 에 도달하는 속도를 측정한다. 이 결과를 표준 과 비교하여 균종을 동정하는데 균종에 따라서 단백질의 구성이 다르므로 균종 동정이 가능하게 된다(Clark et al., 2013).

MALDI-TOF MS법은 신속한 균종 동정 및 아종의 확인, 검체에서 biomarker의 직접 검출, 신속한 분석 등의 장점 이 있기 때문에 법미생물학에서 생물무기의 분석, 알려지 지 않은 단백질의 검출 및 특징 분석, 세균을 속, 종, 균주 레벨까지 특성을 확인하는데 적용할 수 있을 것이다(Ho et al., 2009). 하지만, 생물무기로 사용될 가능성이 있는 미생 물 대부분의 화학분류적 특징(chemotaxonomic signatures) 의 광범위한 데이터베이스 구축이 필수불가결하다.

\section{DNA 마크로어레이(DNA microarray)}

DNA 마크로어레이는 biochip, DNA chip, gene array 등 으로 불리기도 하며, 유전자/유전자 돌연변이(gene/gene mutation) 염기서열의 확인과 유전자의 발현 정도를 확인 하는데 사용된다(Kim et al., 2015). DNA 마크로어레이는 하 나의 칩 상에서 전체 유전체를 모니터링함으로써 연구자 가 수천개의 유전자를 동시에 확인할 수 있는 기법이다 (Heller, 2002; Walsh, 2004).

기존에 배양에 기반한 미생물의 검출과 동정 기법은 대 량의 검사를 수행하기에는 너무 시간이 오래 걸리고, 여 러 개의 미생물이 포함된 검체를 분석하기에는 까다로웠
다. DNA 마크로어레이 기법은 수많은 미생물의 DNA 서 열을 동시에 분석할 수 있고 여러 병원체를 분자적 수준 에서 동정과 특성을 분석할 수 있다는 장점이 있기 때문 에 법미생물학 분야에 적용할 수 있을 것이다(Budowle et al., 2005a; Lents, 2011).

\section{단백질 마크로어레이(Protein microarray)}

단백질 마크로어레이는 매우 적은 양의 서로 다른 정제 된 단백질을 슬라이드에 열과 행을 맞춰 놓은 것으로 이 때 단백질은 매우 순수하고 상당히 농축된 활성을 띤 형 태이어야 한다. 생물테러나 생물범죄와 연관된 질병에서 특정 단백질을 확인함으로써 정확하게 질병을 진단하고 확인하는데 단백질 마크로어레이가 이용될 수 있을 것이 다(Benschop et al., 2012). 즉 수천개의 단백질-단백질 상 호작용(protein-protein interactions)을 확인하고 특이 균종 (species), 혈청형(serotype), 병원형(pathotype), 생물형(biotype) 등을 확인하는 특정 단백질 마커를 활용할 수 있 다(Campbell and Ghazal, 2004; Naistat and Leblanc, 2004; Panicker et al., 2004).

\section{단일 뉴클레오타이드 다형성(Single Nucleotide Poly- morphism; SNPs)}

$\mathrm{SNPs}$ 는 어떤 생명체의 DNA에 있는 특정 위치에서 같 은 종의 서로 다른 유기체가 다른 DNA 서열을 가지는 것을 의미한다. 유전체 내에 SNPs의 빈도, 안전성, 상대 적 분포 등을 분석함으로써 유전 마커로서 가치를 가지게 된다. 유전체 상의 $\mathrm{SNP}$ 위치를 표시한 고밀도 $\mathrm{SNP}$ 지도 가 균종의 유전적 특성과 종분화(speciation)를 분석하는데 이용될 수 있다. 이러한 $\mathrm{SNPs}$ 를 분석함으로써 어떤 균종 
을 특별히 동정하고 특징을 확인하는 유전 마커로서 법 미생물학 분야에서도 활용될 수 있을 것이다(Budowle et al., 2007; Gua et al., 2017).

생물테러나 생물범죄 현장에서 채집된 미생물을 실험실 조건에서 오랜 기간 유지 및 보관하면 균주의 뉴클레오타 이드 다형성은 자연 상태에서의 다형성과 다를 수 있다. 즉 실험실에서 배양과정이 미생물에 선택적 압력을 가하 여 자연 환경에서 발생하는 다형성과 다른 돌연변이를 유 도할 가능성이 있기 때문에 유전체 염기서열 다형성을 분 석할 때는 이런 점을 항상 고려할 필요가 있다(Cummings and Relman, 2002).

\section{다중-유전자자리 변이수 일렬반복 분석(Multiple-Locus Variable Number Tandem Repeat Analysis; MLVA)}

일렬반복 DNA 서열의 서로 다른 숫자를 일렬반복 변 이수(variable number tandem repeat; VNTRs)이라고 하며 이 것은 개별 미생물의 유전체에 걸쳐 존재한다. 즉 일렬반 복 변이수는 특정 미생물의 유전체 안에서 위치마다 다 양하게 나타나고 미생물 균종마다 다르다. 이러한 패턴을 검출하기 위해 표적 미생물의 유전체 $\mathrm{DNA}$ 를 제한효소로 자르면 각 균종마다 독특한 패턴의 특징을 보인다. 이런 특정 패턴을 분석해서 어떤 균종을 확정 동정하게 된다 (van Belkum, 2007).

박테리아의 염색체상에 다수의 유전자자리에 일렬반복 수 차이를 분석하는 것을 다중-유전자자리 변이수 일렬 반복 분석(MLVA)라고 한다. MLVA는 신속하고 수행하기 용이하며 재현성이 뛰어난 분석법이다(James et al., 2014). MLVA는 별개의 일렬반복을 획득 또는 소실됨에 의해 구 별되기 때문에 유전형의 명확한 명칭을 제공한다. 또한 MLVA는 밀접하게 연관된 균주를 구별할 수도 있고, 환 경에서 분리된 미생물들 사이의 명확하게 구별할 수 있 기 때문에 법미생물학 분석에도 활용될 수 있을 것이다 (Ciammaruconi, 2012).

\section{결 론}

미생물은 단일 세포로부터 배양되고 정교한 장치나 숙 련된 전문가 없이도 작은 시설에서 저비용으로 대량생산 이 가능하기 때문에 생물무기로서 아주 좋은 장점을 가지 고 있다. 생물테러나 생물범죄 현장에서 발견된 어떤 미 생물의 기원을 찾아내고 전파 경로를 밝혀 내며 서로 다 른 균주 사이의 분자생물학적 변이를 측정하기 위해서
다양한 법미생물학 기법을 활용할 수 있다(Schutzer et al., 2005).

그동안 법미생물학 발전의 주요 난관은 생물테러와 생 물범죄 현장에서 증거물 채집과 포장, 운송, 보관, 생물무 기 분석 프로토콜의 표준화, 수많은 새로운 분석 기법 결 과의 해석 등이었다. 초창기에는 염기서열 결정법이나 염 기서열 다형성을 비교 평가하는 방법이 미생물 균주의 변 이 서열을 결정하는데 사용되었다(Budowle et al., 2014). 그 러나 DNA 마이크로어레이 같은 높은 처리량 기법으로 대량의 미생물 라이브러리를 스크리닝 하거나 유전자 변 이 패턴을 신속하게 확인할 수 있게 되었다. MADLI-TOF, GC-MS, LS-MS-MS 기법들도 아주 작은 분자나 단백질의 차이를 검출하는데 사용되기 때문에 법미생물학 분석법으 로도 활용성이 높다(Motley et al., 2013). 생물무기로 사용 되는 많은 미생물 균주들이 표현형 또는 생리학적 평가에 서 매우 높은 유사성을 보이기 때문에, 균종 사이의 유전 자 변이를 분석해서 그들의 차이를 구별해내는 비교 유 전체 염기서열 결정법(comparative genome sequencing)이 병원체의 분자계통발생학적 정보를 제공하는데 유용하다 (Massey, 2016).

균종(species) 레벨까지 동정하는 것은 역학적 공중보건 조사에서는 충분할 수 있지만, 법미생물학적 조사에서는 보다 정밀한 균주 확인과 함께 때에 따라서는 하위 균주 (substrain) 레벨까지 정확하게 분석하는 것이 요구되기도 한다. 즉 생물테러나 생물범죄가 의심될 때는 단순히 균 주 타이핑에 더하여 증거물을 생리학적 분석과 함께 유전 체 정보까지 정밀하게 분석하는 것이 필수적이다. 또한 오염된 아포나 꽃가루, 심지어 미생물 배양용 배지의 성 분까지 분석하는 것이 범죄해결의 실마리를 제공하는데 도움이 될 것이다. 생물 및 미생물 환경인자 정보, 미생물 유전학, 진화학, 생리학, 생태학적 과학적 정보가 충분히 제공될 때 법미생물학적 분석은 가장 효과적일 것이다. 전체 게놈 염기서열 분석법(whole genome sequencing)이 법 미생물학적 기법으로의 가치가 더해질 것으로 사료된다 (Broomall et al., 2015). 신뢰성, 재현성, 안정성을 가진 표준 화된 분석 기법, 각 지역별 미생물군집(microbiome) 분석 과 함께 전세계적으로 보편적인 분석 프로토콜과 풍부한 법미생물 데이터베이스 구축이 법미생물학의 발전에 기여 할 것이다.

\section{ACKNOWLEDGEMENTS}

This research was supported by the Soonchunhyang University 
Research Fund and by Basic Science Research Program through the National Research Foundation of Korea (NRF) funded by the Ministry of Education (NRF-2017R1D1A1B03032960).

\section{CONFLICT OF INTEREST}

The authors have no conflicts of interest to disclose.

\section{REFERENCES}

Baron E. Specimen Collection, Transport, and Processing: Bacteriology, in Manual of Clinical Microbiology, (Jorgensen J, Pfaller M, Carroll K, Funke G, Landry M, Richter S, Warnock D. Eds), 2015. pp. 270-315. doi: 10.1128/9781555817381.ch18. ASM Press. Washington, DC, USA.

Baron E, Thomson R. Specimen Collection, Transport, and Processing: Bacteriology, in Manual of Clinical Microbiology (Versalovic J, Carroll K, Funke G, Jorgensen J, Landry M, Warnock D. Eds), 2011. pp. 228-271. doi: 10.1128/9781555816728.ch16. ASM Press. Washington, DC, USA.

Belser LW, Mays EL. Specific inhibition of nitrite oxidation by chlorate and its use in assessing nitrification in soils and sediments. Applied and Environmental Microbiology. 1980. 39: 505-510.

Benschop CC, Quaak FC, Boon ME, Sijen T, Kuiper I. Vaginal microbial flora analysis by next generation sequencing and microarrays; can microbes indicate vaginal origin in a forensic context? International Journal of Legal Medicine. 2012. 126: 303-310.

Broomall SM, Ait Ichou M, Krepps MD, Johnsky LA, Karavis MA, Hubbard KS, Insalaco JM, Betters JL, Redmond BW, Rivers BA, Liem AT, Hill JM, Fochler ET, Roth PA, Rosenzweig $\mathrm{CN}$, Skowronski EW, Gibbons HS. Whole-genome sequencing in microbial forensic analysis of gamma-irradiated microbial materials. Applied and Environmental Microbiology. 2015. 82: 596-607.

Budowle B, Beaudry JA, Barnaby NG, Giusti AM, Bannan JD, Keim P. Role of law enforcement response and microbial forensics in investigation of bioterrorism. Croatian Medical Journal. 2007. 48: 437-449.

Budowle B, Connell ND, Bielecka-Oder A, Colwell RR, Corbett CR, Fletcher J, Forsman M, Kadavy DR, Markotic A, Morse SA, Murch RS, Sajantila A, Schmedes SE, Ternus KL, Turner SD, Minot S. Validation of high throughput sequencing and microbial forensics applications. Investigative Genetics. 2014.
5: 9-26.

Budowle B, Johnson MD, Fraser CM, Leighton TJ, Murch RS, Chakraborty R. Genetic analysis and attribution of microbial forensics evidence. Critical Reviews in Microbiology. 2005a. 31: $233-254$.

Budowle B, Schutzer SE, Ascher MS, Atlas RM, Burans JP, Chakraborty R, Dunn JJ, Fraser CM, Franz DR, Leighton TJ, Morse SA, Murch RS, Ravel J, Rock DL, Slezak TR, Velsko SP, Walsh AC, Walters RA. Toward a system of microbial forensics: From sample collection to interpretation of evidence. Applied and Environmental Microbiology. 2005b. 71: 2209 -2213 .

Budowle B, Schutzer SE, Burans JP, Beecher DJ, Cebula TA, Chakraborty R, Cobb WT, Fletcher J, Hale ML, Harris RB, Heitkamp MA, Keller FP, Kuske C, Leclerc JE, Marrone BL, McKenna TS, Morse SA, Rodriguez LL, Valentine NB, Yadev J. Quality sample collection, handling, and preservation for an effective microbial forensics program. Applied and Environmental Microbiology. 2006. 72: 6431-6438.

Budowle B, Schutzer SE, Morse SA, Martinez KF, Chakraborty R, Marrone BL, Messenger SL, Murch RS, Jackson PJ, Williamson P, Harmon R, Velsko SP. Criteria for validation of methods in microbial forensics. Applied and Environmental Microbiology. 2008. 74: 5599-5607.

Campbell CJ, Ghazal P. Molecular signatures for diagnosis of infection: Application of microarray technology. Journal of Applied Microbiology. 2004. 96: 18-23.

Ciammaruconi A. Microchip capillary electrophoresis of multilocus vntr analysis for genotyping of bacillus anthracis and yersinia pestis in microbial forensic cases. Methods in Molecular Biology. 2012. 830: 381-390.

Clark AE, Kaleta EJ, Arora A, Wolk DM. Matrix-assisted laser desorption ionization-time of flight mass spectrometry: A fundamental shift in the routine practice of clinical microbiology. Clinical Microbiology Reviews. 2013. 26: 547-603.

Cummings CA, Relman DA. Genomics and microbiology. Microbial forensics--"cross-examining pathogens". Science. 2002. 296: 1976-1979.

Fenselau C, Demirev PA. Characterization of intact microorganisms by maldi mass spectrometry. Mass Spectrometry Reviews 2001. 20: 157-171.

Gua Y, Zhab L, Yuna L. Potential usefulness of snp in the 16s rrna gene serving as informative microbial marker for forensic attribution. Forensic Science International: Genetics Supplement Series. 2017. 6: e451-e452. 
Heller MJ. DNA microarray technology: Devices, systems, and applications. Annual Review of Biomedical Engineering. 2002. 4: 129-153.

Ho YP, Reddy PM, Chen CT, Lo AA. Mass spectrometry in microbial forensics. Forensic Science Review. 2009. 21: 25-50.

Hosokawa-Muto J, Fujinami Y, Mizuno N. Evaluation of the universal viral transport system for long-term storage of virus specimens for microbial forensics. Journal of Forensic and Legal Medicine. 2015. 34: 29-33.

James M, Melcher U, Fletcher J. Evaluating the impacts of stressors of pseudomonas syringae pathovar tomato on the effectiveness of multi-locus variable number tandem repeat analysis and multi-locus sequence typing in microbial forensic investigations. Investigative Genetics. 2014. 5: 10-18.

Javan GT, Finley SJ, Abidin Z, Mulle JG. The thanatomicrobiome: A missing piece of the microbial puzzle of death. Frontiers in Microbiology. 2016. 7: 225-231.

Jung YS, Lee KW, Kim HS, Kim SM, Shin JH, Jung SH, Yong DE. Identification of Microorganisms, in Diagnostic Microbiology. 2017. pp. 148-149. Seoheung Press. Seoul, Korea.

Kim M, Zorraquino V, Tagkopoulos I. Microbial forensics: Predicting phenotypic characteristics and environmental conditions from large-scale gene expression profiles. PLoS Computational Biology. 2015. 11: e1004127.

Kotula AW, Pierson MD, Emswiler BS, Guilfoyle JR. Effect of sample transport systems on survival of bacteria in ground beef. Applied and Environmental Microbiology. 1979. 38: 789-794.

Kuiper I. Microbial forensics: Next-generation sequencing as catalyst. EMBO reports. 2016. 17: 1085-1087.

Lederberg J. Infectious history. Science. 2000. 288: 287-293.

Lents NH. Current and Future Uses of DNA Microarrays in Forensic Science, in Forensic Chemistry Handbook (Kobilinsky L. Eds), 2011. doi: 10.1002/9781118062241.ch10. John Wiley \& Sons, Inc., Hoboken, NJ, USA.

Marshall L GM, Boyce SG, MacNeil S, Freedlander E, Kudesia G. Effect of glycerol on intracellular virus survival: Implications for the clinical use of glycerol-preserved cadaver skin. Burns. 1995. 21: 356-361.

Martiny JB, Bohannan BJ, Brown JH, Colwell RK, Fuhrman JA, Green JL, Horner-Devine MC, Kane M, Krumins JA, Kuske CR, Morin PJ, Naeem S, Ovreas L, Reysenbach AL, Smith VH, Staley JT. Microbial biogeography: Putting microorganisms on the map. Nature Reviews Microbiology. 2006. 4: 102-112.

Massey SE. Comparative microbial genomics and forensics. Microbiology Spectrum. 2016. 4: EMF-0001-2013.
McBride G, Gilpin B. Statistical considerations in environmental microbial forensics. Microbiology Spectrum. 2016. 4: EMF0005-2015.

Motley ST, Redden CL, Sannes-Lowery KA, Eshoo MW, Hofstadler SA, Burans JP, Rosovitz MJ. Differentiating microbial forensic qper target and control products by electrospray ionization mass spectrometry. Biosecurity and Bioterrorism. 2013. 11 107-117.

Naistat DM, Leblanc R. Proteomics. Journal of Environmental Pathology, Toxicology and Oncology. 2004. 23: 161-178.

Panicker RC, Huang X, Yao SQ. Recent advances in peptide-based microarray technologies. Combinatorial Chemistry \& High Throughput Screening. 2004. 7: 547-556.

Petersen CE, Valentine NB, Wahl KL. Characterization of microorganisms by maldi mass spectrometry. Methods in Molecular Biology. 2009. 492: 367-379.

Rasko DA, Worsham PL, Abshire TG, Stanley ST, Bannan JD, Wilson MR, Langham RJ, Decker RS, Jiang L, Read TD, Phillippy AM, Salzberg SL, Pop M, Van Ert MN, Kenefic LJ, Keim PS, Fraser-Liggett CM, Ravel J. Bacillus anthracis comparative genome analysis in support of the amerithrax investigation. Proceedings of the National Academy of Sciences of the United States of America. 2011. 108: 5027-5032.

Read TD, Salzberg SL, Pop M, Shumway M, Umayam L, Jiang L, Holtzapple E, Busch JD, Smith KL, Schupp JM, Solomon D, Keim P, Fraser CM. Comparative genome sequencing for discovery of novel polymorphisms in bacillus anthracis. Science. 2002. 296: 2028-2033.

Schmedes SE, Sajantila A, Budowle B. Expansion of microbial forensics. J Clin Microbiol. 2016. 54: 1964-1974.

Schutzer SE, Budowle B, Atlas RM. Biocrimes, microbial forensics, and the physician. PLoS Medicin. 2005. 2: e337.

Taylor LH, Latham SM, Woolhouse ME. Risk factors for human disease emergence. Philosophical Transactions of the Royal Society of London. Series B, Biological Sciences. 2001. 356: 983-989.

United States Center for Disease Control and Prevention. Emergency Preparedness and Response. Bioterrorism Agents/Disease [Online.] Center for Disease Control and Prevention, Atlanta, GA, USA. 2017. https://emergency.cdc.gov/agent/agentlistcategory.asp.

United States Federal Bureau of Investigation. F. B. I. handbook of forensic services. [Online.] Federal Bureau of Investigation, Washington, DC, USA. 2013. https://www.fbi.gov/filerepository/handbook-of-forensic-services-pdf.pdf/view 
van Baare J, Buitenwerf J, Hoekstra MJ, du Pont JS. Virucidal effect of glycerol as used in donor skin preservation. Burns. 1994. 20: Suppl 1: S77-80.

van Baare J, Cameron PU, Vardaxis N, Pagnon J, Reece J, Middelkoop E, Crowe SM. The 1998 lindberg award. Comparison of glycerol preservation with cryopreservation methods on hiv-1 inactivation. The Journal of Burn Care \& Rehabilitation. 1998. 19: 494-500.

van Belkum A. Tracing isolates of bacterial species by multilocus variable number of tandem repeat analysis (mlva). FEMS Immunology and Medical Microbiology. 2007. 49: 22-27.

Walsh SJ. Recent advances in forensic genetics. Expert Review of
Molecular Diagnostics. 2004. 4: 31-40.

Wegerhoff F. It's a bug's life — specimen collection, transport, and viability. Micobe. 2006. 1: 180-184.

Wilson ML. General principles of specimen collection and transport. Clinical Infectious Diseases. 1996. 22: 766-777.

https://doi.org/10.15616/BSL.2018.24.2.55

Cite this article as: Eom YB. Microbial Forensics: Bioterrorism and Biocrime. Biomedical Science Letters. 2018. 24: 55-63. 